\title{
Clinicopathological Study of Thyroid Swellings with \\ on Geographical Some Emphasis Distribution: A Hospital Based Analysis
}

\author{
Kusum Borsaikia, ${ }^{1}$ Mukul Patar ${ }^{2}$
}

\section{Introduction}

\section{ABSTRACT}

Thyroid swellings/goiter are still prevalent in north east part of India. Apart from its sub-Himalayan location the areas along the river Brahmaputra suffer from flooding every year and there is also frequent changing of river course, thought to be another reason for iodine depletion in soil of this region(3).

$\underline{\text { Aim }}$

To determine the incidence of thyroid swellings and distribution among different sections of society and geographical areas, and to evaluate the role of FNAC in the diagnosis and management and find out its accuracy by comparing with histopathology. Materials and methods

In the present study, total 212 patients with thyroid swellings attending department of ENT of a state medical college during the period from January 2013 to December 2015 and undergone FNAC at department of Pathology were taken into consideration. $\underline{\text { Results }}$

Out of 212 cases major fraction (52.83\%) were hailed from areas along the Brahmaputra river followed by patients (33.96\%) from tea gardens and adjacent areas. Patients belonging to tribal communities constituted 45.28\%, whereas patients from tea workers section of society formed the second majority (34.9\%). Female male ratio of cases was 5:1. Majority of patients were from 21-40 years age group with mean age of 37.2 years. Cytology results of 212 cases showed colloid goiter $73.58 \%$, adenomatous goiter $8.49 \%$, thyroiditis $9.9 \%$, hurthle cell neoplasm $1.41 \%$, follicular neoplasm 4.24\%, papillary carcinoma $1.41 \%$, papillary carcinoma of follicular variant $0.47 \%$ and medullary carcinoma in $0.47 \%$ cases. Histopathology was possible in 65 cases and compared with FNAC results with accuracy rate of $89.23 \%$.

\section{Conclusion}

Frequent flooding and changes of river course may be one of the reasons for high prevalence of thyroid swellings and goiter along the Brahmaputra valley apart from its sub-Himalayan location. Consumption polluted drinking water and goitergenous food stuffs may be another reason of high incidence. FNAC is an easy, rapid, reliable, less invasive, low cost technique for diagnosis of thyroid swellings.

$\underline{\text { Keywords }}$

Goiter; Thyroid Neoplasms; Incidence; Aspiration Biopsy, Fine-Needle; Drinking Water; Iodine

$\mathrm{E}$ nlargement of thyroid gland or goitre is a common manifestation of iodine deficiency and its incidence is high in iodine deficient areas. Despite

1 - Dept. of Pathology, Jorhat Medical College, Jorhat, Assam

2 - Dept. of ENT, Jorhat Medical College, Jorhat, Assam Corresponding author:

Dr Mukul Patar

email: patarmukul@gmail.com the salt iodization programme by Govt of India goitre is still widely prevalent in some areas of northeastern India. According to ICMR Bulletin (Vol. 26, June 1996) no state in the country was believed to be free from Iodine Deficiency Disorders.

Patients with thyroid swelling or goitre gave history of taking iodized salt for years. Pollution and bacteriological impurity of drinking water act as goitrogenic agents by raising the bodily demand of iodine. ${ }^{1}$ Surveys conducted by National Goitre Survey Team of the Director General 
of Health Services during the past three decades have detected a high prevalence of endemic goitre in different states. ${ }^{2}$ Iodine content of staple food (rice) and drinking water was found to be poor in sub Himalayan zone of India. $^{2}$

In the north eastern part of India environmental iodine deficiency is one of the principal reasons for high prevalence of goitre and thyroid swelling. Frequent flooding and changes of river course are the major causes of iodine depletion in the soil of this region. ${ }^{3} \mathrm{We}$ have also come across significant number of patients coming with thyroid swelling to our institution for diagnosis and treatment. As a tertiary referral centre major bulk of patients to our Institute are from Jorhat and Golaghat districts and few of them from adjacent Sibsagar, Nagaon and Lakhimpur districts of Assam.

Thyroid swellings are very superficial, easily visible and display an intriguing range of lesions widely differing in biological behaviour and are source of concern for the patient and a diagnostic dilemma for physicians. ${ }^{4}$ FNAC is a well-accepted and established OPD procedure used in the primary diagnosis of palpable thyroid swelling with high sensitivity and specificity.

\section{Aims and Objectives}

1. The objective of this study is to determine the overall incidence and clinical analysis of thyroid swellings with some emphasis on geographical and community distribution of cases.

2. The frequency of occurrence of different variants of thyroid swellings and their age and sex distribution.

3 . To evaluate the results of thyroid FNAC and correlate with histopathological results, wherever available.

\section{Materials and Methods}

In this retrospective study patients with clinically diagnosed thyroid swellings attending the OPD of department of ENT who had undergone FNAC at department of Pathology, State Medical College and Hospital from January 2013 to December 2015 were taken into consideration. The detailed information each patient including name, age, sex, address, category, community, religion, presenting complaints, duration of thyroid swelling, general examination, local examination stating site, size and other characteristics of thyroid swellings were retrieved from records and noted in a prescribed proforma.

Patients were subjected to clinical palpation, mobility during swallowing was assessed, lymph node examination, thyroid profile and FNAC were done. Patients were then treated surgically or medically. Prior to FNA, thyroid glands were palpated carefully and details of the procedure were explained to the patients. The patients were made to lie supine with the neck extended and after taking all aseptic precautions aspiration was done by a $23 \mathrm{G}$ needle attached to a 20 $\mathrm{ml}$ disposable syringe. Two to three passes were made in each case.

For cystic swellings, cyst contents were aspirated and centrifuged and sediments stained for cytological examination. The slides were stained by May-GrunwaldGiemsa (MGG), hematoxylin and eosin (H and E) and Papanicolaou (pap) stains, wherever necessary. Results of cytopathological slides examination were correlated with clinical diagnosis of all cases and histopathological results of operated patients. Out of total 212 cases $65(30.66 \%)$ cases underwent either hemithyroidectomy, subtotal thyroidectomy or total thyroidectomy in our hospital and histopathological examination was done in department of Pathology.

\section{Results}

A total of 212 cases with palpable thyroid swelling were examined at Department of ENT, State Medical College and Hospital during the period from January 2013 to December 2015 and after thorough clinical examination the patients were subjected to FNAC at Department of Pathology. From the medical records and history, it was observed that majority of patients were from areas along the Brahmaputra river (112 cases, 52.83\%) and patients living in and around tea gardens formed the second major group (72 cases, 33.96\%). On the other hand, majority of patients belonged to tribal (mongoloid origin) communities (96 cases, $45.28 \%$ ), mostly living 
Table I : Geographical and Community distribution of cases $(n=212)$

\begin{tabular}{|c|c|c|c|c|c|}
\hline \multicolumn{6}{|c|}{ GEOGRAPHICAL DISTRIBUTION OF CASES } \\
\hline $\begin{array}{c}\text { No. of } \\
\text { patients } \\
\text { hailing } \\
\text { from areas } \\
\text { along } \\
\text { the river } \\
\text { Brahma- } \\
\text { putra }\end{array}$ & 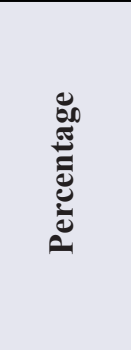 & $\begin{array}{c}\text { No. of } \\
\text { pa-tients } \\
\text { from tea } \\
\text { gardens } \\
\text { and adja- } \\
\text { cent places }\end{array}$ & 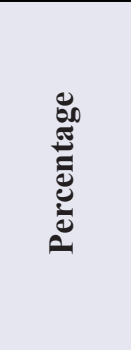 & $\begin{array}{c}\text { No. of } \\
\text { pa-tients } \\
\text { from other } \\
\text { places }\end{array}$ & 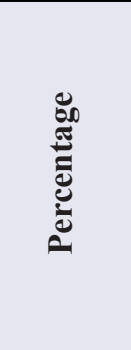 \\
\hline 112 & $52.83 \%$ & 72 & $33.96 \%$ & 28 & $13.20 \%$ \\
\hline \multicolumn{6}{|c|}{ COMMUNITY DISTRIBUTION OF CASES } \\
\hline $\begin{array}{l}\text { No. of } \\
\text { patients } \\
\text { belonging } \\
\text { to tribal } \\
\text { (mongol- } \\
\text { oid origin) }\end{array}$ & 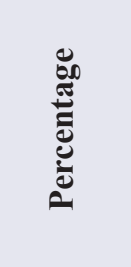 & $\begin{array}{l}\text { No. of pa- } \\
\text { tients be- } \\
\text { longing to } \\
\text { tea tribes } \\
\text { (Adivasi) }\end{array}$ & 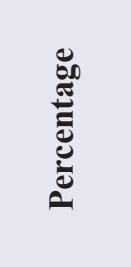 & $\begin{array}{c}\text { No. of } \\
\text { pa-tients } \\
\text { from other } \\
\text { sec-tion of } \\
\text { soci-ety }\end{array}$ & 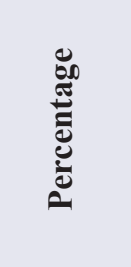 \\
\hline 96 & $45.28 \%$ & 74 & $34.9 \%$ & 42 & $19.8 \%$ \\
\hline
\end{tabular}

in villages along the Brahmaputra river and tea tribe section (Adivasi community) of society formed the second major group (74 cases, $34.9 \%$ ) (Table I).

Out of total 212 patients 35 cases (16.5\%) were male and 177 cases $(83.49 \%)$ were female with a female male ratio 5:1(Table II). The age of patients ranged from 11 to 78 years with a mean age of 37.2 years. It was observed that majority of patients with thyroid swellings were in the 21 to 40 years age group (Table II).

The major presenting symptom in all the patients was diffuse and/or nodular swelling of thyroid (100\%) and other less common symptoms were pain in thyroid region in $21(9.9 \%)$ patients, hoarseness or change of voice in 3 cases $(1.4 \%)$ and difficulty in swallowing in 7 $(3.3 \%)$ patients. Respiratory difficulty was observed in one $(0.47 \%)$ patient only. Duration of swelling for less than 3 months was observed in $33(15.56 \%)$ patients and thyroid swellings between 3 months to one year duration was noted in $141(66.5 \%)$ patients and more than one year in $38(17.92 \%)$ cases.

FNAC results of the study group are shown in
Table III. In 9 cases FNAC specimens were hemorrhagic and/or inadequate but diagnosis was done only after repeat FNAC. In our study, FNAC results of 195 (91.98\%) patients showed non-neoplastic lesions and 17 cases $(8.01 \%)$ showed neoplastic lesions (Table III). Based on cytological study of 212 cases, it was observed that non-neoplastic lesions were more common (91.98 $\%)$ then the neoplastic lesions $(8.01 \%)$. The most common non-neoplastic lesion was colloid goitre with 156 cases $(73.58 \%)$ followed by thyroiditis in 21 cases $(9.9 \%)$ and adenomatous goiter in 18 cases $(8.49 \%)$. Among the neoplastic lesions follicular neoplasm was more common (9 cases, $4.24 \%$ ) and 5 cases showed malignancy $(2.36 \%)$.

Out of total 212 cases, 65 cases were operated and their histopathological diagnosis correlated with FNAC diagnosis with accuracy rate of $89.23 \%$. Out of 5 cytologically diagnosed malignant thyroid swellings, correlation with histopathological findings were done in 4 cases and found $100 \%$ accuracy (Table-IV). 
Table II : Distribution of Study Population as per Age and Sex

\begin{tabular}{|c|c|c|c|c|}
\hline & & & & \\
\hline & & & & \\
\hline
\end{tabular}

\section{Discussion}

In the present study, majority of patients with thyroid swelling/goitre were from villages/areas along the Brahmaputra river and most of them belonged to tribal communities of mongoloid origin, followed by tea tribes (Adivasi) hailing mostly from Jorhat and Golaghat districts and few of them from Sibsagar and Lakhimpur districts of Assam. This high incidence of goitre can be explained by possibility of iodine depletion in the soil along the river Brahmaputra due to frequent flooding and change of river course. ${ }^{3}$

Studies also observed low iodine level in the soil along the river Brahmaputra ${ }^{3}$ and in drinking water of sub-Himalayan region. ${ }^{5}$ Secondly high incidence of thyroid swelling among tea tribes can be explained by pollution and bacteriological impurity of drinking water acting as goitrogenic agent, raising bodily demand of iodine $^{1}$ and consumption of goitrogenous foodstuff. ${ }^{3}$

Age of the patients ranged from 11 to 78 years with a mean age of 37.2 years, which correlated with studies conducted by Handa et $\mathrm{al}^{6}(37.69+14.93)$, Gupta et $\mathrm{al}^{7}$ ( 38.9) and Sathiyamurthy et $\mathrm{al}^{8}$ with (36.5). But not correlating with studies conducted by Silverman et $\mathrm{al}^{9}$ and Arvintham et $\mathrm{al}^{10}$ with mean ages of 44.8 and 46 years respectively. In this study out of total 212 cases, 35 cases $(16.5 \%)$ were male and 177 cases $(83.49 \%)$
Table III : FNAC results of 212 patients

\begin{tabular}{|c|c|c|}
\hline & & \\
\hline NON-NEOPLASTIC & 195 & $91.98 \%$ \\
\hline Colloid goiter & 156 & $73.58 \%$ \\
\hline Adenomatous Goiter & 18 & $8.49 \%$ \\
\hline Thyroiditis & 21 & $9.9 \%$ \\
\hline NEOPLASTIC & 17 & $8.01 \%$ \\
\hline Benign & 12 & $5.65 \%$ \\
\hline Hurthle cell neoplasm & 3 & $1.41 \%$ \\
\hline Follicular neoplasm & 9 & $4.24 \%$ \\
\hline Malignant & 5 & $2.35 \%$ \\
\hline Papillary carcinoma & 3 & $1.41 \%$ \\
\hline Medullary carcinoma & 1 & $0.47 \%$ \\
\hline
\end{tabular}

were female with male female ratio 1:5, which correlated with the studies conducted by Ghazaleh et $\mathrm{al}^{11}$ (16\% male and 84\% female), Alam et al ${ }^{12}(13 \%$ male and $87 \%$ female) and Sathiyamurthy et al 8 (20\% male and $80 \%$ female) and Parikh et al ${ }^{13}$ where male female ratio was 1:5.1. Regarding distribution of cases, cytological study of 212 cases showed nodular/colloid goitre in 156 cases(73.58\%), which was correlated with study conducted by Sathiyamurthy et $\mathrm{al}^{8}$ (69.09\%) but the incidence was higher when compared to study conducted by Gupta et $\mathrm{al}^{7}(52 \%)$, Silverman et $\mathrm{al}^{9}$ $(50.4 \%)$ and Nggada et $\mathrm{al}^{14}(57.97 \%)$. Adenomatous goitre was diagnosed in 18 cases $(8.49 \%)$, the number of which was higher when compared with study conducted by Handa et $\mathrm{al}^{6}(2.53 \%)$. Thyroiditis was diagnosed in 21 cases $(9.9 \%)$, which was lower than when compared to study conducted by Handa et $\mathrm{al}^{6}(27.41 \%)$. Hurthle cell neoplasm accounted for 3 cases $(1.41 \%)$, similar to study conducted by Handa et $\mathrm{al}^{6}(1.38 \%)$, but lower 
Table IV : Correlation between FNAC and histopathological findings $(n=65$ patients)

\begin{tabular}{|c|c|c|c|c|c|c|c|}
\hline \multirow{2}{*}{ 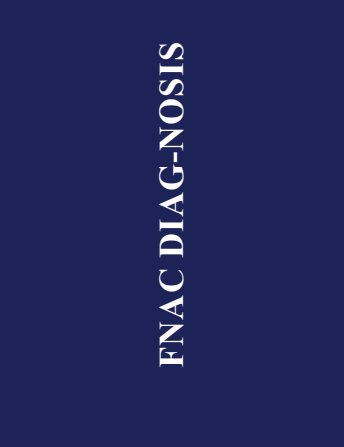 } & \multicolumn{7}{|c|}{ HISTOPATHOLOGICAL DIAGNOSIS } \\
\hline & 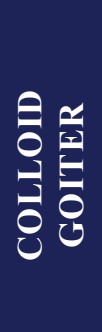 & 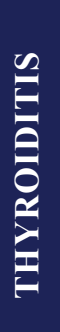 & 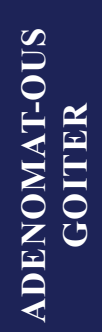 & 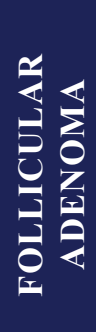 & 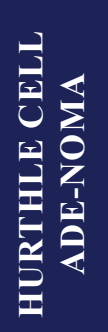 & 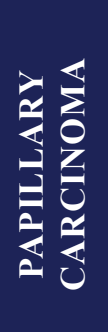 & 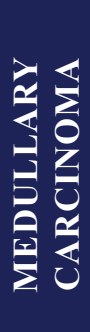 \\
\hline Colloid goiter & 40 & - & 1 & 2 & - & - & - \\
\hline Thyroiditis & - & - & - & - & - & - & - \\
\hline Adenomatous goiter & 3 & - & 7 & - & 1 & - & - \\
\hline Follicular neoplasm & - & - & - & 5 & - & - & - \\
\hline Hurthle cell neoplasm & - & - & - & - & 2 & - & - \\
\hline Papillary carcinoma & - & - & - & - & - & 3 & - \\
\hline Medullary carcinoma & - & - & - & - & - & - & 1 \\
\hline TOTAL & 43 & 0 & 8 & 7 & 3 & 3 & 1 \\
\hline
\end{tabular}

then Gupta et $\mathrm{al}^{8}(8 \%)$. The number of cases detected as follicular neoplasm was 9 (4.24\%), which correlated with studies conducted by Silverman et $\mathrm{al}^{9}(5.2 \%)$ and Sathiyamurthy et $\mathrm{al}^{8}(5.45 \%)$, but higher than Handa et $\mathrm{al}^{6}(1.84 \%)$ and lower than Gupta et $\mathrm{al}^{7}(16 \%)$. In the present study 5 cases were cytologically diagnosed as malignant and among this papillary carcinoma was diagnosed in 3 cases $(1.41 \%)$, which was lower than Sathiyamurthy et al8 $(2.72 \%)$, Nggada et $\mathrm{l}^{14}(4.3 \%)$, Handa et $\mathrm{al}^{6}(2.30 \%)$ but much lower when compared to study by Nart et $\mathrm{al}^{15}(42.34 \%)$. Papillary carcinoma of follicular variant was diagnosed in 1 case $(0.47 \%)$, which was also much lower when compared to study conducted by Nart et $\mathrm{al}^{15}(15.3 \%)$. Medullary carcinoma was also diagnosed in 1 case $(0.47 \%)$, and almost correlated with studies conducted by Silverman et $\mathrm{al}^{9}$ $(0.6 \%)$, Handa et $\mathrm{al}^{6}(0.69 \%)$, Sathiyamurthy et $\mathrm{al}^{8}$ $(0.90 \%)$, but the incidence was much lower than Nggada et $\mathrm{al}^{12}(4.3 \%)$ and Nart et $\mathrm{al}^{15}(5.4 \%)$.

In our study histopathological studies were conducted in 65 cases and correlated with their cytological diagnosis. Total 43 cases of cytologically diagnosed nodular and colloid goitre were operated and subjected to histopathological studies; 40 cases matched the cytological diagnosis. But in one case histopathology diagnosis came out as adenomatous goitre and 2 cases as follicular adenoma. In the present study 18 cases were diagnosed as adenomatous goiter and histopathological examinations were possible in 11 cases, which showed adenomatous goiter in 7 cases, colloid goitre in 3 cases and hurthle cell adenoma in 1 case. Out of 9 cases diagnosed as follicular neoplasm on cytology, histopathological studies were possible in 5 cases and all of them showed follicular adenoma with addition of another 2 cases which were initially diagnosed as colloid goitre by cytology. Cytological diagnosis of Hurthle cell neoplasm was done in 3 cases and histopathological study was possible in 2 cases and found $100 \%$ diagnostic accuracy by FNAC, with addition of one case where initial cytological diagnosis 
was adenomatous goiter. Papillary and medullary carcinoma were detected in 3 and 1 cases respectively by cytology and subsequent histopathological examination of all these cases were found to be similar with $100 \%$ accuracy. Statistical analysis of results of our study shows the overall diagnostic accuracy of FNAC to be $89.23 \%$, almost similar to study conducted by Parikh et $\mathrm{al}^{14}(90.24 \%)$.

\section{Conclusion}

In conclusion, frequent flooding of Brahmaputra valley and changes of river course, attributed to be one of the reasons for high prevalence of thyroid swelling and goitre in Jorhat and Golaghat districts of Assam, apart from its sub-Himalayan location. As pollution of drinking water is related to intensity of goitre, taking of contaminated water and goitrogenous foodstuff may be one reason of high incidence of goitre or thyroid swelling among the tea tribes, probably due to lack of proper health education.

At the same time, FNAC is an easy, rapid, reliable, less invasive, low cost technique for diagnosis of thyroid swellings. It can be performed as an OPD procedure with high diagnostic accuracy, for palpable thyroid swellings, thus avoiding unwanted surgery and decreasing morbidity.

\section{References}

1. Kelly FC, and Snedden WW. Prevalence and Geographical Distribution of Endemic Goiter. WHO Monograph. 1960; 44:27-200

2. Sharma NR. Thyroid Dysfunction in Suspected Population of Kangra Valley in Himachal Pradesh, India. Biomed and Pharma. J2013; 6:415-9.
3. Hazarika NC, Mahanta J. Environmental Iodine Deficiency and Goitre Prevalence in a Block Area of the North Eastern Region: A Retrospective analysis. J Hum Ecol.2004; 15:113-7.

4. Mandreker SRS, Nadkarni NS, Pinto RGW, Meneaes S. Role of fine needle aspiration as the initial modality in the investigation of thyroid lesions. Acta Cytol. 1995; 39:898-904.

5. Ramalingaswami V., Subramanyam TAV and Deo MG. The Etiology of Himalayan Endemic Goiter. Lancet. 1961;1:791.

6. Handa U., Garg S., Mohan H, Nagarkar N. Role of fine needle aspiration cytology in diagnosis and management of thyroid lesions: A study on 434 patients. J of Cytology. 2008; 25:13-7.

7. Gupta M, Gupta S, Gupta VB. Correlation of fine needle aspiration cytology with histopathology in the diagnosis of solitary thyroid nodule. (online) Hindawi Access to Res J of Thyr Research. 2010. (URL:http://www.sage-hindawi.com. Vol.2010

8. Sathiyamurthy K., Patil MS, Mirje M. Fine needle aspiration cytology study of thyroid lesions. International $\mathrm{J}$ of Curr Research. 2014; 6: 9230-3.

9. Silverman FJ, West RL, Larkin EW, Park HK, Finley JL, Melvin S. The role of fine needle aspiration biopsy in the rapid diagnosis and management of thyroid neoplasm. Cancer. 1986; 57:1164-70.

10. Arvinthan T, Banagala ASK, Gamage KJPK (2007): Use of fine needle aspiration cytology on thyroid lumps. Galle Med J. 2007; 12:25-7.

11. Ghazaleh N., Haddadinezhad S, Jafari M. Fine needle aspiration cytology of thyroid nodules: correlation with surgical histopathology. Terk Jem. 2008; 12:73-4.

12. Alam M, Qureshi H, Jan QA (2010): Accuracy of FNAC as a diagnostic modality in the management of solitary thyroid nodule. J. Med. Sci. 2010; 18:94-6.

13. Parikh UR, Goswami HM, Shah AM, Mehta NP, Gonsai RN. Fine needle aspiration cytology (FNAC) study of thyroid lesions (study of 240 cases). Guj Med J. 2012; 67:25-30.

14. Nggada HA, Musa AB, Gali BM, Khalil MIA. Fine needle aspiration cytology of thyroid nodule(s): a Nigerian tertiary hospital experience. The Internet J of Pathology. 2006; 5:1-8

15. Nart D, Ertan Y, Argon A, Sezak M, Veral A, Makey O. Role of fine needle aspiration cytology and intraoperative diagnosis in the diagnosis of thyroid nodules. Turk. J. Pathol. 2010; 26(1):48-54. 